\title{
Composition and early-age temperature regime in massive concrete foundation
}

\author{
Lam Van Tang ${ }^{1, *}$, Chuc Trong Nguyen ${ }^{1}$, Boris Bulgakov ${ }^{1}$, and Anh Ngoc Pham ${ }^{2}$ \\ ${ }^{1}$ Moscow State University of Civil Engineering, Yaroslavskoe shosse, 26, Moscow, 129337, Russia \\ ${ }^{2}$ Ruhr Universität Bochum, IC6 -137. Universitätstr 150, 44801 Bochum, Germany
}

\begin{abstract}
The usage of monolithic concrete technology in massive structure construction has created a need for a more detailed design focused on crack control. In this study, the American standard ACI 211.109 and absolute volume method were used to determine the composition of heavy weight concrete for the high-rise building foundation. The concrete block temperature behavior has been analyzed by a three-dimensional thermal model in program Midas Civil. The conducted studies' result provided the possibility of obtaining heavy weight concrete from Vietnam local raw materials regarding to the concrete mixture workability of $16 \mathrm{~cm}$ standard cone, compressive strength of $42.3 \mathrm{MPa}$ and average tensile strength of $3.5 \mathrm{MPa}$ at the age of 28 days. According to the model analysis results, the maximum temperatures of the massive concrete foundation at the first (after 72 hours) and second pour (after 144 hours) from the beginning of construction are respectively $55.7^{\circ} \mathrm{C}$ and $65.5^{\circ} \mathrm{C}$. In addition, the temperature differences at the core of each concrete pours with respect to the concrete outer portion, which induces a risk of through cracking in structure body or surface were determined.
\end{abstract}

\section{Introduction}

The rise of economic development and population in the urban areas lead to future increasing activity in residential high-rise construction and office buildings. High-rise buildings are usually in the pile form and raft foundation due to a combination of vertical, lateral and overturning forces $[1,2]$. However, massive concrete foundations are taken down the temperature levels during the casting operation phase so as to avoid early-age cracking problems.

According to [3-5], concrete early-age behavior has proven to be decisive with regard to massive concrete constructions as gravity dams, thick foundations, hydropower projects, piers, etc. Fresh concrete hardening associated with exothermic chemical hydration process, raises the concrete temperature within the structure domain. At the same time, because of the large size of structures, the heat released during the cement hydration at an early age is difficult to redistribute from the inner layers to the outside. Additionally, the cooling of massive concrete by ambient air produces considerably different temperatures between

* Corresponding author: lamvantang@gmail.com 
concrete center and surfaces points. In conclusion, the considerable thermal gradients are results of low thermal conductivity of young concrete. These thermal gradients aggregated with external as well as internal restraint to volume changes induce stresses. In study [6], cracking happens in concrete block when the tensile stress becomes higher than that of concrete.

The temperature distribution in concrete structures and its evolution with time depend on thermal parameters such as evolving concrete properties, ambient conditions, placement temperature, phased casting operation sequence, etc., making highly non-linear problem [7]. Many researchers have proposed different approaches for numerical simulation of temperature evolutions in early age concrete $[8,9]$. Analysis the temperature regime and temperature evolutions are extremely important for assessing the probability of concrete structure cracks at an early age of hardening concrete [10]. Practically, the controlling organization is often such difficulty, especially, in massive concrete foundation of high-rise building underground parts.

Furthermore, existing industrial waste, such as fly ash, ash residue, slag, etc. can be used to replace Portland cement in concrete mixtures. The benefits of using fly ash as a partial cement replacement in concrete are well documented. This replacement reduces the thermal gradient, leading to reduce of thermal cracking [11]. Therefore, it has been widely used since then in different structures such as gravity dams, bridge piers, bridge abutments, and mass concrete footings [12].

This research paper deals with the study on the thermal behavior of massive concrete foundation produced from Vietnamese local raw materials and $20 \%$ mass fly ash.

\section{Materials and methods}

\subsection{Materials}

a). Portland cement (PC): type CEM I $42.5 \mathrm{~N}$, manufactured at "Hoang Thach" factory (Vietnam), specific weight of $3.15 \mathrm{~g} / \mathrm{cm}^{3}$. The maximum heat of cement hydration is 295 $\mathrm{J} / \mathrm{g}$ at 28 days. The results of physical properties, mechanical properties and cement's mineralogical composition are presented in Table 1 and 2 respectively.

Table 1. Mineralogical Composition of "Hoang Thach" cement

\begin{tabular}{|c|c|c|c|c|}
\hline \multicolumn{5}{|c|}{ Mineral composition (\%) } \\
\hline $\mathrm{C}_{3} \mathrm{~S}$ & $\mathrm{C}_{2} \mathrm{~S}$ & $\mathrm{C}_{3} \mathrm{~A}$ & $\mathrm{C}_{4} \mathrm{AF}$ & Other \\
\hline 54.5 & 23.7 & 4.8 & 13.5 & 3.5 \\
\hline
\end{tabular}

Table 2. Physical and mechanical properties of "Hoang Thach" Portland cement CEM I 42.5N

\begin{tabular}{|c|c|c|c|c|c|c|c|}
\hline \multirow{2}{*}{$\begin{array}{l}\text { Specific weight } \\
\qquad\left(\mathrm{g} / \mathrm{cm}^{3}\right)\end{array}$} & \multirow{2}{*}{$\begin{array}{c}\text { Surface } \\
\text { area } \\
\left(\mathrm{cm}^{2} / \mathrm{g}\right)\end{array}$} & \multicolumn{2}{|c|}{ Time of setting $(\mathrm{min})$} & \multicolumn{3}{|c|}{ Compressive strength (MPa) } & \multirow{2}{*}{$\begin{array}{c}\text { Standard } \\
\text { consistency } \\
(\%)\end{array}$} \\
\hline & & Initial & Final & 3 days & 7 days & 28 days & \\
\hline 3.15 & 3625 & 132 & 237 & 35.8 & 41.4 & 48.3 & 29.1 \\
\hline
\end{tabular}

b). Quartz sand (QS): originally from the golden sand of "Lo River" (Vietnam), $\mathrm{M}_{\mathrm{K}}=$ 3.15 , specific weight of $2.66 \mathrm{~g} / \mathrm{cm}^{3}$. The volume of compacted state is $1560 \mathrm{~kg} / \mathrm{m}^{3}$.

c). Crushed limestone (CL) (Vietnam) with the size of $5-20 \mathrm{~mm}$, specific weight of $2.67 \mathrm{~g} / \mathrm{cm}^{3}$. The volume of the compacted state is $1680 \mathrm{~kg} / \mathrm{m}^{3}$.

d). Fly Ash (FA) TPP "Vung Ang" (Vietnam) class F with specific weight of $2.35 \mathrm{~g} / \mathrm{cm}^{3}$ and the volume of natural porous state is $778 \mathrm{~kg} / \mathrm{m}^{3}$. Retained content on sieve $0.09 \mathrm{~mm}$ is $13.2 \%$. The chemical composition of the FA is shown in Table 3. 
Table 3. Chemical compositions of FA TPP "Vung Ang"

\begin{tabular}{|l|c|c|c|c|c|}
\hline \multicolumn{5}{|c|}{ Average chemical composition (\%) } \\
\hline $\mathrm{SiO}_{2}$ & $\mathrm{Al}_{2} \mathrm{O}_{3}$ & $\mathrm{Fe}_{2} \mathrm{O}_{3}$ & $\mathrm{SO}_{3}$ & LOI & \\
\hline 54.91 & 23.10 & 5.67 & 0.37 & 6.51 & other \\
\hline \multicolumn{2}{l}{ Note: } \\
\hline
\end{tabular}

e). Ordinary clean tap water (W) was used for both mixing concrete and curing of test specimens.

\subsection{Methods}

Calculation method of concrete mixture composition is applied in accordance with ACI 211.109 (American) and the volume method. According to ASTM C143, the concrete mixture workability is determined by the standard slump cone with dimensions of $100 \times 200 \times 300 \mathrm{~mm}$. The compressive strength and tensile strength of heavyweight concrete are determined by Russian standard GOST 10180-2012. These test samples are demolded after 24 hours later casting and placed in a $25 \pm 50 \mathrm{C}$ water curing tank until the experiments. The heavyweight concrete compressive strengths are measured at the ages of $1,3,7,14$ and 28 days. The concrete elasticity modulus is determined by the compressive strength value at 28 days by American standard ACI 318-2005. While, the cement hydration heat is determined by standard ASTM C186-17. Furthermore, the Midas Civil program can calculate the maximum temperature at the massive concrete foundation center and its temperature behavior.

\section{Results and discussion}

\subsection{The object study}

The case study object is a monolithic concrete foundation of the high-rise building, shaped rectangular box with $10 \mathrm{~m}$ length, $8 \mathrm{~m}$ width and $3 \mathrm{~m}$ thick, founded on a solid limestone bedrock (shown in Figure 1). The high-rise building foundation, in the urban areas of the Vietnam Northern part in the summer, is constructed via two phased casting operations, i.e., $1.5 \mathrm{~m}$ concrete foundation thickness is poured at once and remained after 3 days.

(a)

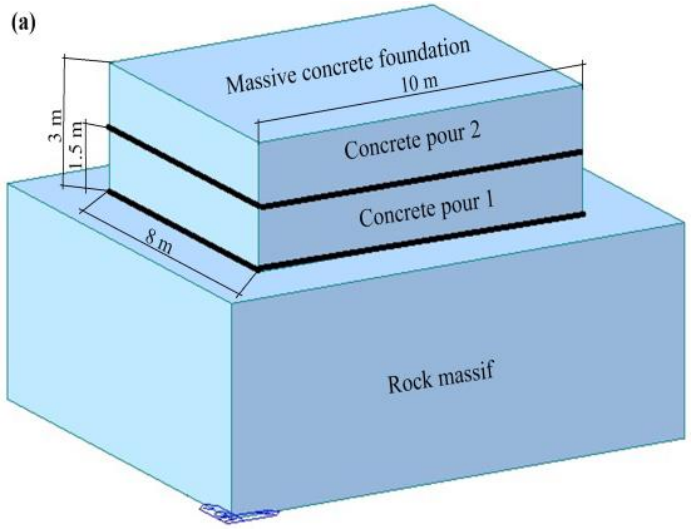

(b)

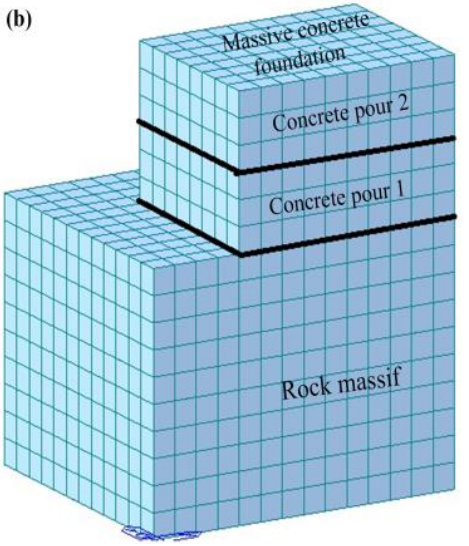

Fig. 1. Geometry of the massive concrete foundation: (a) three-dimensional (3D) model and the two phases of concrete pouring and (b) 3D finite-element model-mesh of $1 / 4$ the structure 


\subsection{Calculation of the concrete mixture composition}

Development of high performance concrete must possess:

- The fresh concrete effect on workability is determined by the standard slump cone 150-175 mm.

- The compressive strength at the age of 28 days is higher than $40 \mathrm{MPa}$.

- Using fly ash TPP "Vung Ang" to replace $20 \%$ of the mass cement in concrete mixture. The relative volume of entrapped air is not more than $1 \%$.

The standard ACI 211.1-02, which is used to determine the concrete mixture composition, requires the standard slump cone of $150-175 \mathrm{~mm}$ and allows to obtain $40 \mathrm{MPa}$ compressive strength concrete at the age of 28 days with ordinary hardening. The fresh concrete properties as well as the heavyweight concrete properties are represented in Table 4 and 5 .

Table 4. Mixture composition and properties of concrete mixture

\begin{tabular}{|c|c|c|c|c|c|c|c|c|}
\hline \multicolumn{5}{|c|}{ Concrete mixture compositions $\left(\mathrm{kg} / \mathrm{m}^{3}\right)$} & \multicolumn{3}{|c|}{ Fresh concretes properties } \\
\hline PC & FA & BID $^{(2)}$ & QS & CL & W & $\frac{\mathrm{W}}{B I D}{ }^{(3)}$ & $\begin{array}{c}\text { Average density } \\
\left(\mathrm{kg} / \mathrm{m}^{3}\right)\end{array}$ & $\begin{array}{c}\text { Slump } \\
(\mathrm{cm})\end{array}$ \\
\hline 412 & 103 & 515 & 591 & 1008 & 216 & 0.42 & 2330 & 16 \\
\hline
\end{tabular}

Note: ${ }^{(2)} B I D=P C+F A$ and ${ }^{(3)} \frac{\mathrm{W}}{B I D}-$ ratio by weight.

Table 5. Properties of heavyweight concrete

\begin{tabular}{|c|c|c|c|c|c|c|}
\hline $\begin{array}{c}\text { Average density } \\
\text { of concrete } \\
\left(\mathrm{kg} / \mathrm{m}^{3}\right)\end{array}$ & \multicolumn{5}{|c|}{ Average compressive strength at different } & $\begin{array}{c}\text { Average tensile strength } \\
\text { at the age of } 28 \text { days } \\
\text { aPd }\end{array}$ \\
\cline { 2 - 6 } & 1 days & 3 days & 7 days & 14 days & 28 days & \\
\hline 2324 & 10.4 & 24.1 & 29.6 & 38.7 & 42.3 & 3.5 \\
\hline
\end{tabular}

According to ACI 318-2005, the relationship between the elasticity modulus of heavyweight concrete $\left(\mathrm{E}_{\mathrm{c}}\right)$ and the value of compressive strength at 28 days $\left(\mathrm{R}^{28} \mathrm{c}\right)$ is determined by formula (1):

$$
E_{c}=4730 \sqrt{R_{c}^{28}}=4730 \sqrt{42.3} \approx 31000(\mathrm{MPa})
$$

It can be seen from Table 4 that the concrete mixture composition calculation with $20 \%$ mass fly ash and the specified workability allow to obtain the required strength concrete. In addition, the test results showed that the concrete strength is obtained quickly, high earlystrength concrete. In details, the compressive strength at the age of 1 and 3 days are respectively $24.6 \%$ and $56.9 \%$ in comparison to 28 days period.

\subsection{Fundamentals of the heat transfer theory temperature in material and concrete}

Significant thermal induced stresses are developed as a result of heat field of cementitious material hydration in heavyweight concrete. The temperature distribution through the foundation's bridge and its time evolution depend on the following elements:

- Concrete properties and

- Cement amount.

- Climatic factors.

- Construction procedure.

- Thickness of lifts.

- Initial temperature of concrete mixture, and

- Interval between their successive placements. 
These thermally induced stresses can be significant enough to provoke concrete structure cracks. The recently sophisticated software development (based on advanced numerical methods) and the continually increasing computer power allow the complex analyses for such temperature stress problems.

Finite element method of temperature field: According to the studies [13], at any point in the calculation field $\mathrm{R}$, the unstable temperature field $\mathrm{T}(\mathrm{x}, \mathrm{y}, \mathrm{z}, \tau)$ must satisfy the following continuous thermal conduction equation (2):

$$
\frac{\partial}{\partial x}\left(k_{x}(\mathrm{~T}) \frac{\partial T}{\partial x}\right)+\frac{\partial}{\partial y}\left(k_{y}(\mathrm{~T}) \frac{\partial T}{\partial y}\right)+\frac{\partial}{\partial z}\left(k_{z}(\mathrm{~T}) \frac{\partial T}{\partial z}\right)+G=\rho c \frac{\partial T}{\partial \tau},
$$

where: $\mathrm{T}$ - the material temperature $\left({ }^{0} \mathrm{C}\right)$;

$k_{x}(T), k_{y}(T), k_{z}(T)$ - the thermal conductivities $\left(W / m^{\circ} \mathrm{C}\right)$ dependent on the temperature in the directions $\mathrm{x}, \mathrm{y}$ and $\mathrm{z}$, respectively;

$\mathrm{G}$ - the rate of internal heat generation (internal energy) per unit volume $\left(\mathrm{W} / \mathrm{m}^{3}\right)$;

$\mathrm{c}$ - the specific heat $\left(\mathrm{J} / \mathrm{kg} .{ }^{0} \mathrm{C}\right)$;

$\rho$ - the density concrete $\left(\mathrm{kg} / \mathrm{m}^{3}\right)$;

$\tau$ - time (day).

To solve equation (2), it is necessary to know two main types of boundary conditions containing Drichlet and Cauchy boundary [14], which can be written respectively as:

$$
T=T_{p}, \quad k_{x} \frac{\partial T}{\partial x} l_{x}+k_{y} \frac{\partial T}{\partial y} l_{y}+k_{z} \frac{\partial T}{\partial z} l_{z}+q+h\left(T_{s}-T_{f}\right)=0
$$

where: $T_{p}$ - the values of the nodal temperatures on the boundaries $\left({ }^{0} \mathrm{C}\right)$;

$\mathrm{q}$ - heat from surface $\left(\mathrm{kcal} / \mathrm{m}^{3}\right)$;

$\mathrm{h}$ - the film coefficient;

$\mathrm{T}_{\mathrm{s}}$ - temperatures at the boundary nodal points $\left({ }^{0} \mathrm{C}\right)$;

$\mathrm{T}_{\mathrm{f}}$-the ambient temperature $\left({ }^{0} \mathrm{C}\right)$;

$1_{x}, l_{y}$ and $l_{z}$ - the direction cosines of the outward normal to the surface under consideration on the $\mathrm{x}, \mathrm{y}$ and $\mathrm{z}$ axes respectively.

The temperature condition determination for massive concrete structures is quite complex due to not only the structure spatial shape but also the internal and external influence factors. Therefore, approximate methods are used in massive monolithic reinforced concrete structure design.

\subsection{Fundamentals of the heat transfer theory temperature in material and concrete}

The purpose of this article is to use the Midas Civil computer program to determine maximum temperatures and temperature evolutions by time in the massive foundation of heavyweight concrete (shown in Table 2).

The ambient temperature significantly effects on the maximum temperature at concrete block center during the hardening process. Typically, it is determined by the average temperature monthly, seasonally and/or annually. According to the study [15], the summer temperature in Northern Vietnam change according to the equation (4):

$$
t_{\text {air }}=26.5+5 \sin \left(\frac{2 \pi \tau}{24}\right)\left({ }^{0} \mathrm{C}\right)
$$

where: $\mathrm{t}_{\text {air }}$ - daily average air temperature $\left({ }^{0} \mathrm{C}\right)$ and $\tau$ - time (hours).

In this study, the initial temperature of laying concrete mixtures, which depends on the concrete mixture temperature, is $20^{\circ} \mathrm{C}$. The initial temperature of rock massif in the foundation is considered as $25^{\circ} \mathrm{C}$. 
Table 6 presents the heavyweight concrete and rock massif under high-rise building foundation properties, which are considered as inputs for analyzing the temperature regime during the concrete's mixture hardening at normal condition.

Table 6. Material properties in temperature behavior analysis

\begin{tabular}{|l|c|c|}
\hline \multicolumn{1}{|c|}{ Properties } & Heavyweight concrete & Rock massif \\
\hline Thermal conductivity coefficient $\left(\mathrm{W} /\left(\mathrm{m} .{ }^{0} \mathrm{C}\right)\right.$ & 2.63 & 2.80 \\
\hline Specific heat coefficient $\left(\mathrm{J} / \mathrm{kg} .{ }^{0} \mathrm{C}\right)$ & 1.05 & 0.85 \\
\hline Mass density $\left(\mathrm{kg} / \mathrm{m}^{3}\right)$ & 2324 & 2700 \\
\hline Elastic modulus $\left(\mathrm{N} / \mathrm{m}^{2}\right)$ & $3.1 .10^{10}$ & $2.0 .10^{10}$ \\
\hline Thermal expansion Coefficient $\left(1 /{ }^{0} \mathrm{C}\right)[16]$ & $1.0 .10^{-5}$ & $1.0 .10^{-5}$ \\
\hline Poisson's ratio $[16]$ & 0.2 & 0.2 \\
\hline Maximum cement hydration heat at 28 days $(\mathrm{J} / \mathrm{g})$ & 295 & - \\
\hline Amount of cement $\left(\mathrm{kg} / \mathrm{m}^{3}\right)$ & 412 & - \\
\hline The concrete mixture temperature of $\left({ }^{0} \mathrm{C}\right)$ & 20 & - \\
\hline
\end{tabular}

Taking advantage of the axial symmetry of the study object, the 3D solid is discretized using 8-noded elements as shown in Figure 2. Two types of boundary are considered including boundary 1 (free contact with air) with convection coefficient value of 10 $\mathrm{W} / \mathrm{m}^{2}{ }^{0} \mathrm{C}$ and boundary 2 (wood shuttering) with a value of $7.5 \mathrm{~W} / \mathrm{m}^{2}{ }^{0} \mathrm{C}$ [17] (in Figure 2).

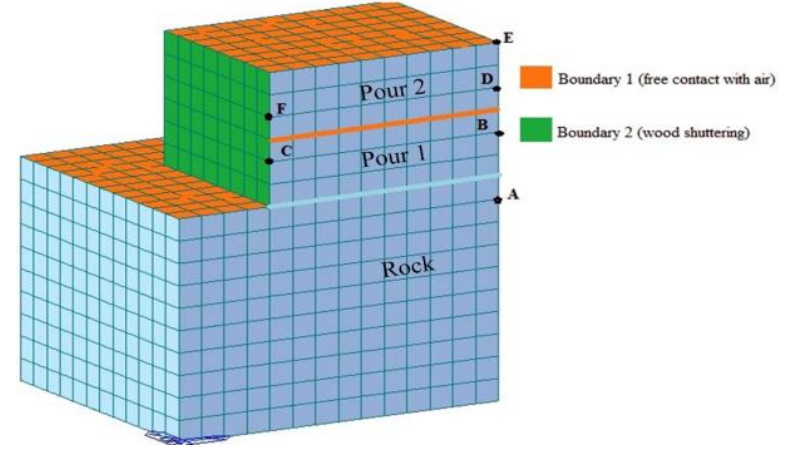

Fig. 2. Thermal boundary conditions and the six nodes for temperature behaviour analysis of the massive concrete foundation

Temperature developments of the studied nodes in concrete body are marked by six points A, B, C, D, E and F (refer Figure 2). The temperature evolutions at 4 points (A, B, D and $\mathrm{E}$ ) along the axis at the concrete foundation center and at another 2 points $\mathrm{C}$ and $\mathrm{F}$ in the surfaces, which are located at different heights from the instant of the first pour till 10 days, are depicted in Figure 3.

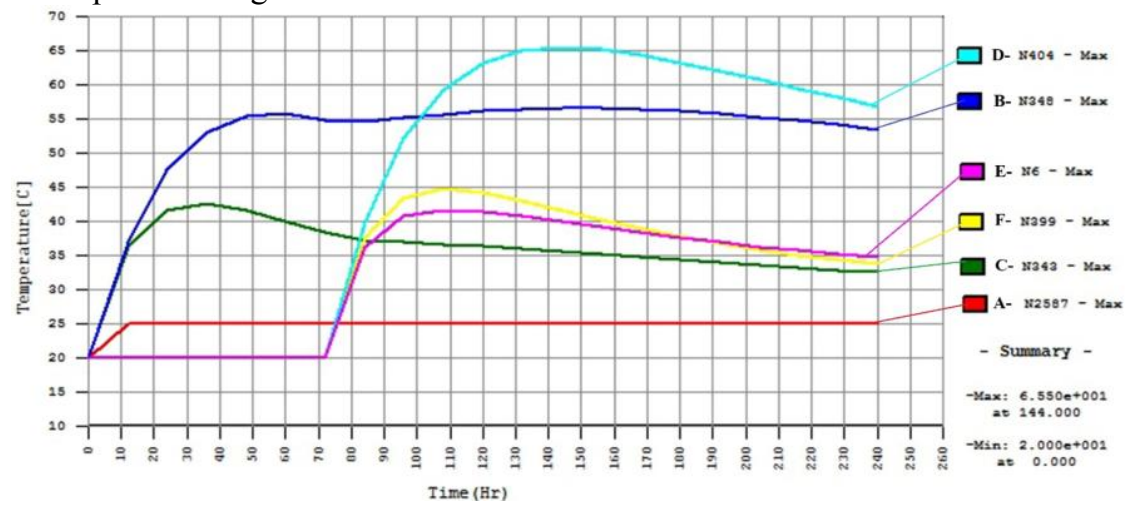

Fig. 3. Temperature evolutions at six different points of concrete in the high-rise building foundation 
The temperature profiles after 72 hours and 144 hours from the beginning of construction at the first and second stages in the concrete foundation $3 \mathrm{D}$ model are portrayed in Figure 4.
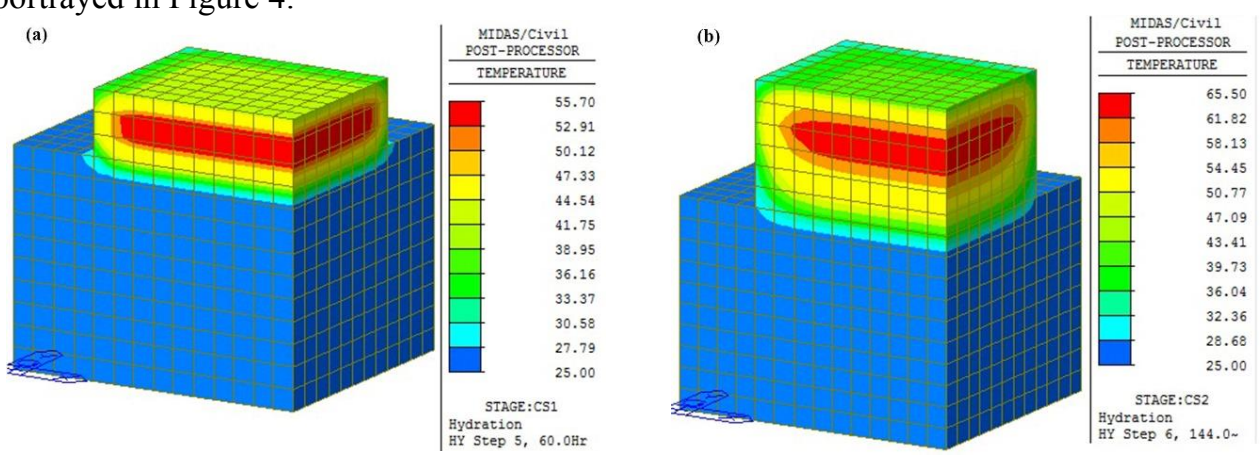

Fig. 4. 3D temperature distribution process in body of concrete foundation: (a) after 60 hours from the beginning of construction in first concrete pour and (b) after 144 hours from the beginning of construction in second concrete pour

It can be noted from the Figures 3 and 4 that, once the first pour is cast, the temperature of the pour increases and reaches maximum temperature of $55.7^{\circ} \mathrm{C}$. Since then, it gradually decreases in the course of time hardening concrete due to the convective heat transfer at the boundaries. When the second pouring is performed, heat in concrete body generates during the cement hydration increases and also reaches maximum temperature of $65.5^{\circ} \mathrm{C}$, and further increases the temperature of the concrete in pour 1 as well as a part of the rock massif.

Furthermore, it can be noted that cement hydration raises the temperature at the core of each concrete pours, producing considerably different temperatures with respect to the outer concrete portion, which induces risk of through cracking in body structure or surface. At the first construction stage, the temperature difference between the center (point $\mathrm{B}$ ) and the center rock massif (point $\mathrm{A}$ ) is $30.7^{\circ} \mathrm{C}$, while this difference between point $\mathrm{B}$ and the concrete foundation surface (point $\mathrm{C}$ ) is only $14.7^{\circ} \mathrm{C}$. Meaningfully, the risk of through thermal cracking in the bottom position in contact with the rock's surface are higher than on the outer surface of structure right part. At the second construction stage, the temperature difference between the center (point D) and the surfaces (points D and E) are respectively $23.91{ }^{\circ} \mathrm{C}$ and $25.53^{\circ} \mathrm{C}$. Therefore, the risk of cracking at these points is nearly the same.

\section{Conclusion}

1. It is possible to produce heavyweight concrete from Vietnamese local raw materials and $20 \%$ mass fly ash to build the high-rise building foundation sized $10 \times 8 \times 3 \mathrm{~m}$, with relate to the concrete mixture workability on $16 \mathrm{~cm}$ standard cone, $42.3 \mathrm{MPa}$ compressive strength and $3.5 \mathrm{MPa}$ average tensile strength at the age of 28 days with normal hardening.

2. According to the 3D model in Figure 4 made by the Midas Civil computer program, the maximum temperatures of the massive concrete foundation in the first and second pour (after 72 hours and 144 hours from the beginning of construction) are respectively $55.7^{\circ} \mathrm{C}$ and $65.5^{\circ} \mathrm{C}$.

3. In first concrete pour, the temperature difference between the center (point B) and the center rock massif (point A) is $30.7^{\circ} \mathrm{C}$, while this difference from the surface (point $\mathrm{C}$ ) is only $14.7^{\circ} \mathrm{C}$. Meaningfully, the risk of through thermal cracking in the bottom position in contact with the rock's surface are higher than on the outer surface of structure right part.

4. In second concrete pour, the temperature difference between the center (point D) and the 
surfaces (points D and E) are respectively $23.91{ }^{\circ} \mathrm{C}$ and $25.53{ }^{\circ} \mathrm{C}$. Therefore, the risk of cracking at these points is nearly the same.

Furthermore, this information can be used appropriately for designing the massive concrete foundation of the high-rise building. This measure can bring down the temperature level in concrete body, so as to avoid cracking during and immediately after the casting operations.

\section{References}

1. H. Poulos, Proc. Ins. of Civ. Eng., 163 (2010)

2. M. Li, L. Liang, X. Li, Adva. M. Resea., 368 (2012)

3. R. Faria, M. Azenha, J.A. Figueiras, Cem. Concr. Compos., 28 (2006)

4. Y. Lee, J-K. Kim, Comput. Struct., 87 (2009)

5. B. Klemczak, M. Batog, M. Pilch, A. Zmij, Inter. Conf. Anal. Mod. and New Concep. Concr. Masonry Struc., AMCM, 193 (2017)

6. D.S. Atrushi, Tensile and Compressive Creep of Early Age Concrete: Testing and Modelling (Norway, 2003)

7. M. Azenha, R. Faria, D. Ferreira, Cem. Concr. Comp., 31 (2009)

8. E. Holt, M. Leivo, Cem. Concr. Compo., 26 (2004)

9. Y. Yuan, Z.L. Wan, Cem. Concr. Compo., 32 (2002)

10. B. Kuriakose, B. Nageswara Rao, G. R. Dodagoudar, Proc. Tech., 25 (2016)

11. M. Liwu, D. Min, Cem., Concr. Rese., 36 (2006)

12. R. Szecsy, Concr. Constru., 51 (2006)

13. B. Li, Z. Wang, Y. Jiang, Z. Zhu, Adva. in Mech. Engine., 10 (2018)

14. J. Noorzaei, K. H. Bayagoob, A.A. Abdulrazeg, M.S. Jaafar, T.A. Mohammed, CMES., 47 (2009)

15. N. Q. Hung, J. Water Resou. Enviro. Sc., 22 (2009)

16. I. Abdallah, H. Malkawi, S.A. Mutasher, T.J. Qiu, J. Perfor. of Constr., 17 (2003)

17. R.D. Cook, D.S. Malkus, M.E. Plesha, R.J. Witt, Concepts and application of finite element analysis (Singapore, John Wiley and Sons (Asia) Pte. Ltd., 2005) 